\title{
ANALYSIS OF EDUCATION AND HEALTH QUALITY OF CHILDREN OF INDONESIAN FEMALE MIGRANT WORKERS FAMILIES: A CASE STUDY IN CIANJUR AND INDRAMAYU REGENCIES
}

\author{
Ferry Hadiyanto \\ Arsita \\ Rosleny Marliani \\ ${ }^{1}$ Faculty of Economy and Bussines \\ Universitas Padjadjaran, Indonesia \\ E-mail: ferry.hadiyanto@unpad.ac.id \\ ${ }^{2}$ Faculty of Economy and Bussines \\ Universitas Padjadjaran, Indonesia \\ ${ }^{3}$ Faculty of Psychology \\ Universitas Islam Negeri Sunan Gunung Djati Bandung, Indonesia
}

\begin{abstract}
:
This study is aimed at aims knowing the education and health quality of children of TKW families in Sindanglaka Village, Karangtengah District of Cianjur Regency and Juntinyuat Village, Juntinyuat District of Indramayu Regency. By using survey data of 56 and 48 households in Cianjur and Indramayu Regencies respectively, data is processed using the probit model. The variables used in this research are children academic reports, frequency of children suffering from illness, education expenditure, health expenditures, children ages, education levels of heads of households, children dependence, and family responsibilities. The results show that education expenditure, children ages, and education levels of heads of households have a significant effect on children education, while children health is influenced by the ages of children and family responsibility.
\end{abstract}

Keywords: education, health, education expenses, health expenses, children's age, dependency, responsibility

\section{A. INTRODUCTION}

In accordance with the development of era and advancement of science and technology, the roles of women have shifted (Knight, D. B., Mappen, E. F., \& Knight, S. L., 2011 \& Sylvia Beyer, 2014). Women do not only have a role as homemakers but also as the economic supporters of families and some work as the main source of income (Vandebroek and Van Molle, 2010). This happens in both urban and rural areas where many women work to help their families and some of them work as the Indonesian female migrant workers overseas (Mafruhah, Izza, Totok Sarsito, Evi Gravitiani, 2012) known as Tenaga Kerja Wanita or TKW.

Cianjur and Indramayu Regencies in West Java are two regions sending most TKW overseas and Malaysia and Saudi Arabia are the main destination. According to Wahjuni 
(2007), two factors encourage homemakers to work as a TKW, which are: (a) a self-intention aiming at changing their destiny, improving their family welfare, and fulfilling their needs; and (b) the external drive, which is the influence of their friends, relatives, families, and husband aiming at having houses, fulfilling household equipment, vehicles, and capital for their future business.

On the one hand, working overseas economically gives a positive impact where it gives additional income and raises their prosperity through remittances sent from overseas (Matuzeviciute and Butkus, 2016). However, it has to pay the social cost when working overseas as a TKW if they have to leave their children (Ford, 2016). The shift of children nurturing during the work period makes other family members take care of their children (Seepamore, 2015). Not only the children nurturing, will the education of their children be another issue. First, mothers will not have an opportunity to nurture their children during their work period (Abdul Hakim, Supriyadi, \& Yuniarti, 2012). Secondly, husbands will take over that responsibility as the educators in their family environment, heads of households, and income seekers. Husbands have limited time giving their children education. Some children of TKW families are dropped out from their schools or discontinuing their study in a higher level (Saraswati, 2013).

Some previous research has tried to explain the effect of migration on children like the research conducted by UNICEF Office in Barbados and Eastern Caribbean (2009) that analysed the impact of migration on children. The result shows that, even though it gives a positive impact on family economics, a migration affects the children development negatively. Children left by migrating mothers tend to experience a physical violence and sexual abuse. The lack of parents' attention makes children not confident, have lower learning motivation, experience decreasing nutritious guarantee and heath and these all lead to a high number of dropped out children in Caribbean.

According to the background above, this research tries to analyse the impact of economics and non-economics factors on the education and health qualities of children of TKW families as a case study observed in Cianjur and Indramayu Regencies. The analysis is based on two questions as follows: (1) How do the economics and non-economics factors affect the children education of TKW families in Cianjur and Indramayu Regencies? and (2) How do the economics and non-economics factors affect the children health of TKW families in Cianjur and Indramayu Regencies?

\section{B. METHOD}

\section{Data and Data Sources}

This research uses primary data obtained from a field survey in Sindanglaka Village, Karangtengah District of Cianjur Regency and Juntinyuat Village, Juntinyuat District of Indramayu Regency. Data and information are obtained from deep interviews

The TKW households refer to a household where one of the family members has or is working as a TKW for one year or more and the school-aged child exists. 56 and 48 samples from Cianjur and Indramayu Regencies are taken respectively. 
The majority of respondents of this survey are the husbands of Indonesian Female Migrant Workers (TKW) working for their households. The information obtained includes the Children Academic Reports, frequency of Children suffering from illness, Remittance Proportions allocated to education and health, children ages, education levels of heads of households, Children dependence level/Frequency of departures of TKW, and the responsibility role of nurturing children.

\section{Research Model}

Model 1: The Analysis of Influence of Economic and Non-Economic Factors on the Children Education

$$
E=\beta_{0}+\beta_{1} E D U C E X P+\beta_{2} A G E+\beta_{3} E D U C+\beta_{4} D E P+\beta_{5} R E S P+\varepsilon
$$

Model 2: The Analysis of Influence of Economic and Non-Economic Factors on the Children Health

$$
H=\beta_{0}+\beta_{1} \text { HEALTHEXP }+\beta_{2} A G E+\beta_{3} E D U C+\beta_{4} D E P+\beta_{5} R E S P+\varepsilon
$$

Where:

$\begin{array}{ll}\text { E } & \text { : Children Academic Reports } \\ \text { H } & \text { : Frequency of Children suffering from illness } \\ \text { EDUCEXP } & \text { : Remittance Proportion allocated to education } \\ \text { HEALTHEXP } & \text { : Remittance Proportion allocated to health } \\ \text { AGE } & \text { : Children Ages } \\ \text { EDUC } & \text { : Education levels of heads of households } \\ \text { DEP } & \text { : Children dependence level/Frequency of departures of TKW } \\ \text { RESP } & \text { : Responsibility role of nurturing children }\end{array}$

\section{Literature Review}

\section{Theory of Education Economics}

Education is the primary need of every person as effort to brighten the state since education can help improve the social welfare. Education plays a significant role in the national life to create qualified human resources. Adam Smith (1776) tried to explain the cause of a state welfare by isolating two factors, which are 1) the importance of economics scale, and 2) the creations of skills and human resources development. The second factor has become the main issue concerning the importance of education to improve the economic growth.

\section{Theory of Health Economics}

The research conducted by Hildebrandt and McKenzie (2005) applying health production function of Grossman (1973) can be written mathematically as follows:

$$
H_{i}: f\left(M_{i}, T_{i}, K_{i}, B_{i}, e_{i}\right)
$$


where $M$ is the nutrition and medicine adequacy; $T$ is the quantity of time spent with parents; $\mathrm{K}$ is parents' knowledge about health; and $\mathrm{B}$ is the biological heritage i.e. genetic factor.

Theory of Female Migration

Oishi (2002) tried to explain the gender aspect in the international migration through an integrative approach viewed from (1) macro-level (state), (2) micro-level (individuals), and (3) meso-level (community).

The macro level concept explains the female migration pattern as a result of a migration policy of a nation. According to Lim \& Oishi (1996), the emigration policy treats males and females differently. Some countries exempt male migrants while female migrants are prohibited. Some other countries limit the female migrants based on ages, destinations, and types of jobs. This policy is aimed at pressing the number of female migrants in order to minimise the cases experienced by female migrants in their preferred countries.

The micro level concept explains the female migration pattern as an individual decision. The decision to migrate refers to the intentions of female migrants to work overseas aiming at improving their family prosperity. This concept is applicable in many developing countries like Indonesia where most of migrants are females expecting to get higher income in their preferred countries so that they can fulfil the needs of their families in their countries of origin.

In understanding the meso-level approach (social relations), Oishi (2002) suggested a concept of "social legitimation" as the measuring tool. The social legitimation is established as a norm applicable in a community to support specific behaviours. The social legitimation of female migrants means a set of conducive norms in the international migration deriving from (1) historical heritages, (2) state integration in the economics, (3) female mobility, and (4) gender equality mainly in education. The females' decision to migrate is affected by their social condition of their community of origin, the community's views on female migrants, prohibitions or objections to women working, or the supports to female migrants from the community.

\section{Theory of Child Demands}

A demand on a good is various numbers of good units where consumers will pay various alternatives of good prices. Hereby, the demand law applies that if the price of goods rises, the number of goods demanded by consumers will decrease or ceteris paribus (the others will not change). Otherwise, if the price of goods decreases, the number of goods demanded by consumers will increase or ceteris paribus (the others will not change).

In the economics field, children are considered a commodity like the other household goods i.e. mobile phones, vehicles, refrigerators etc. According to Todaro (2010), many developing countries see children as an investment. This means that children are expected as the additional forces to do farming and life investment in the future. Therefore, determining the family fertility level as well as the number of children expected by a family or "the demand level on children" is a rational economic option for a consumer (in this case, it is a family).

The option to have more children is gained by sacrificing the option on other goods whereas this decision assumes the substitute and income effects. This means that if other factors are considered stable or constant, the expected number of children is directly affected by the 
family income. In contrast, the number of expected children is negatively related to the relative price (maintenance costs) of children as well as the strong desire to have other goods (Todaro and Smith, 2012).

Mathematically, this relation can be stated as follows:

$$
Q_{d}=f\left(Y, P_{c}, P_{x}, T_{x}\right)
$$

where:

$Q_{d}=$ The number of expected children

$Y=$ Family Income Level

$P_{c}=$ The nett child price, which is the margin between the opportunity cost of the time spent by mothers and consideration of all benefits from having children.

$P_{x}=$ Prices of other goods but children.

$T_{x}=$ High or low preferences on goods but children.

In a normal or neo-classic condition, it is expected that the changes of those factors will lead to the changes of the number of children expected by families as explained below: $\frac{\partial Q_{d}}{\partial Y}>0$ means that if the family income rises or become higher, the expectation on the number of children will likely to increase.

$\frac{\partial Q_{d}}{\partial P_{c}}<0$ means that if the nett child price rises, the expectation on the number of children will likely to decrease.

$\frac{\partial Q_{d}}{\partial P_{x}}>0$ means that if the good price rises, the expectation on the number of children will likely to increase.

$\frac{\partial Q_{d}}{\partial T_{x}}<0$ means that if the family preferences on other goods get higher, the expectation on the number of children will likely to be lower.

According to Mahadevan (1986), the nett child price is the opportunity expense added by other expenses to maintain the child sustainability for a better life that is entirely measured by money. The components related to the nett child price are:

1. Emotional Cost: The emotional cost is the emotional load aroused in order to nurture children in the areas of disciplines, good behaviour or moral, worries on health decline, disputes in families, and bad behaviours of children.

2. Economic Cost: The cost aroused to nurture children, keep their health and safety. 
3. Opportunity Cost: Lost of freedom, limited to socialise, lack of opportunity to take care of own self, self-needs, and reduced work opportunities.

4. Physical Need Cost: The cost caused by the increase of household activities (nurturing children, and clothing, housing, and food for children).

5. Family Cost: The emerging of disputes to take care of children and reduced opportunity to love their respective couples.

According to Figure 1, it can be described that the budget lines of $a-b$ shows the limited level of family income where the nett children and other good prices are fixed. Since the other influential factors are considered fixed, the maximum level of family satisfaction lies at dot $B$ with the specific numbers of children and consumed goods. Furthermore, if the nett child price rises while other good price is stable, the intention to have more children will be postponed or cancelled and it will be replaced by consuming other goods. This means that a family must find a lower maximum satisfaction than the previous one and graphically, it is shown by the decrease of maximum satisfaction level as it shifts from lines $B$ to $A$. Therefore, the budget line swings to the left from $a-b$ to $a-b 2$. However, if the family income rises due to more employment opportunities for women or the rise of received wages, the family will have an opportunity to consume more goods and have more children at the same time leading to a maximum family satisfaction. Graphically, the budget line will shift upward to be $a 1-b 1$ and the maximum satisfaction level will shift from $B$ to $D$.

Figure 1. Theory of Children Demands

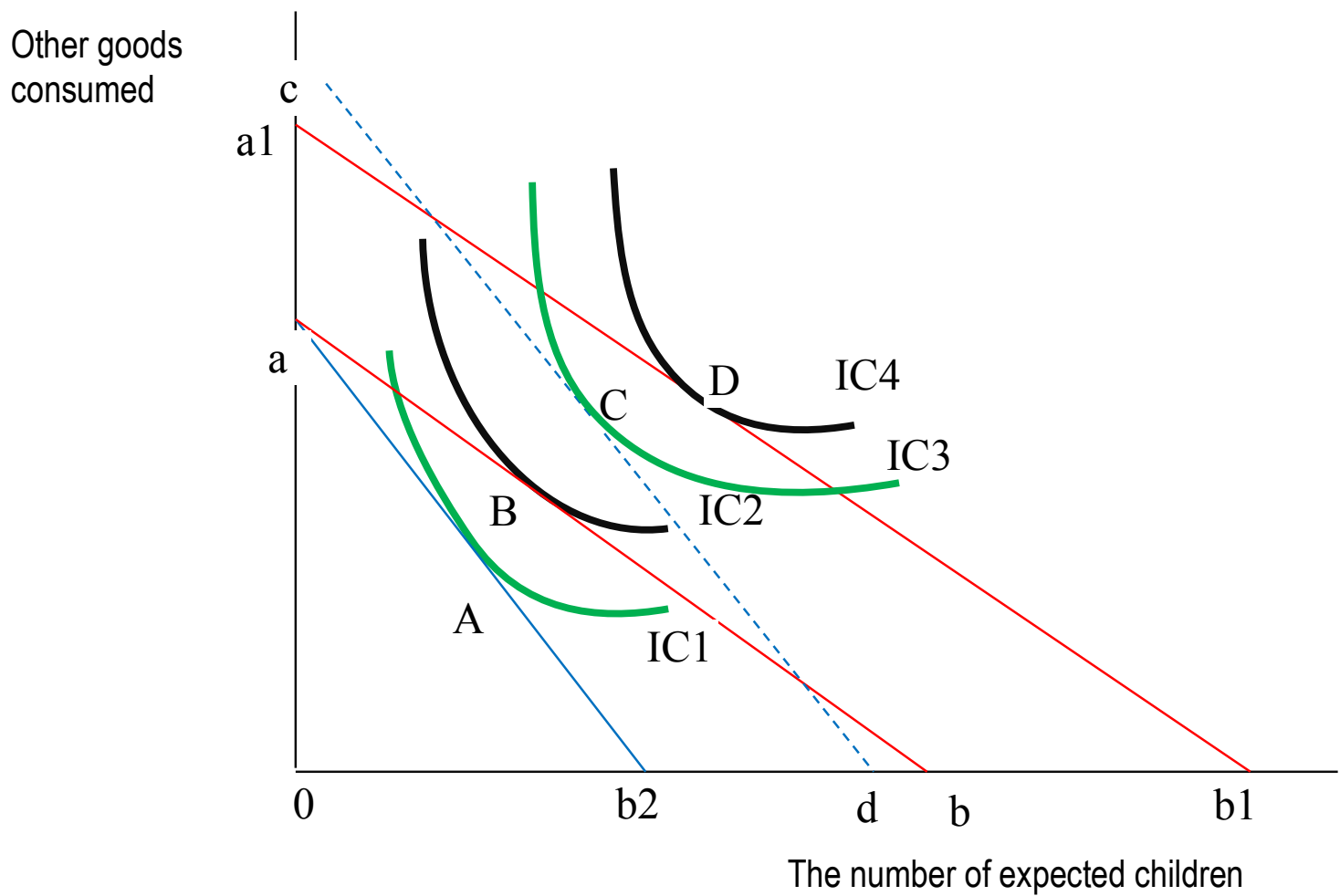

Source: Todaro and Smith, 2012 
If the income increase is in coincidence with the rise of child nett price, i.e. the taxes applied to children or removing subsidies to the fourth children onwards, the budget line that is previously $a-b$ will rotate to the right at c-d line as shown by the dotted budget line. As a result, the new consumption combination between children and other goods will occur and a new maximum satisfaction level of a family will be shown by $C$ dot. Therefore, the number of children expected by a family will reduce and is replaced by consuming other goods since additional income is allocated to the consumption of goods. This mostly happens to lowincome families where additional income is spent to improve their family prosperity.

\section{Previous Research}

The research result conducted by Robert Ssengonz, Gordon F. De Jong, C Shannon Stokes (2002) shows that the migration flows significantly affect the life sustainability of infants and children. Ten percent of children die before turning 5 years of ages depending on the migration status of their mothers. The other significant variables affecting the life sustainability are the education level of parents, the number of family members, length of breastfeeding, and the migration destinations of mothers. The research conducted by Juan Ponce et all shows that a remittance positively and significantly affects the expenditures of migrant families allocated for food, school fees, and medicines. However, this research has not found a significant effect on the human resources development. The remittance only affects the expenditures of health and education and reduces poverty in a short term. However, to analyse its impact on the human development, a longer time is required. The results of research conducted by CEPS/INSTEAD, Luxembourg and CRES - University of Dakar, Senegal (2011) shows that a migration significantly affects the school enrolments (for migrants going to Europe). More family members in the households migrate but the number of children of 7-12 years of ages going to schools has relatively decreased and most of them have become child labours.

Figure2. Frame of Thinking

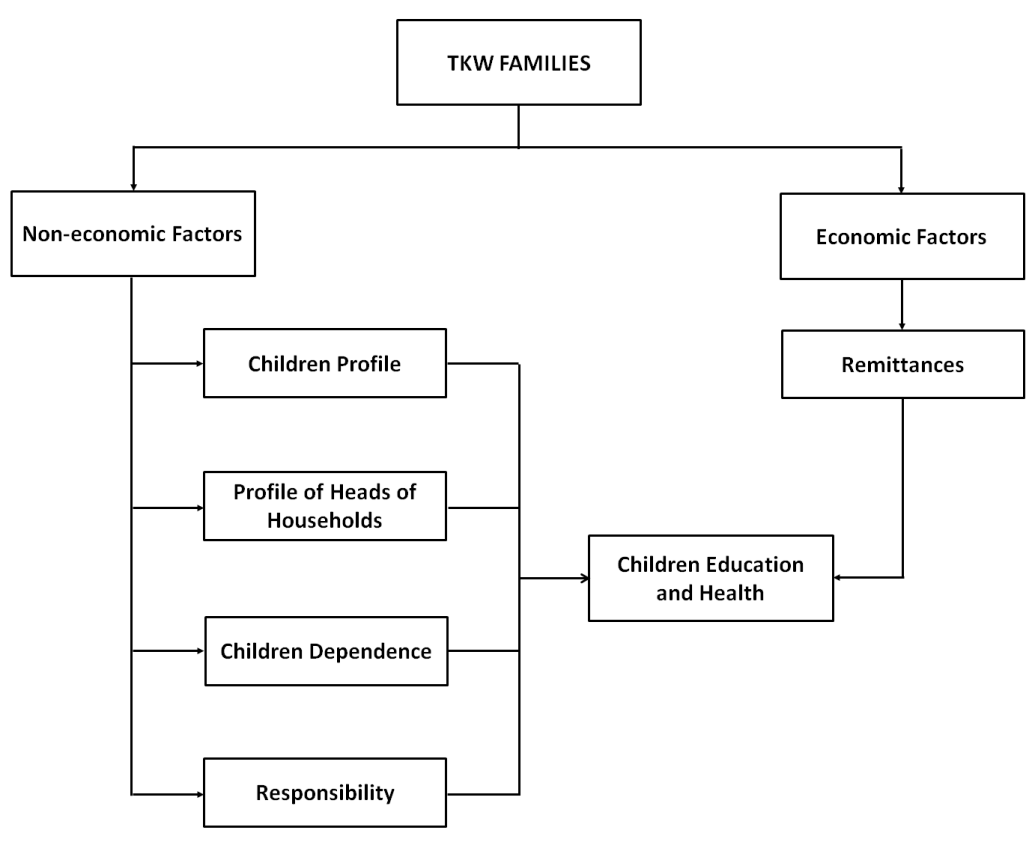




\section{RESULT AND DISCUSSION}

By using the analysis model of probit on 56 households in Cianjur Regency and 48 households in Indramayu Regency, the obtained result is as follows:

Table 1. The Influence of Economic and Non-Economic Factors on the Children Education

\begin{tabular}{|c|c|c|c|}
\hline Variable & $\mathbf{Z}_{\text {count }}$ & Prob & Influence \\
\hline EDUCEXP & 1.974905 & 0.0483 & Significant at $\alpha$ 5\% \\
\hline AGE & -2.377830 & 0.0174 & Significant at $\alpha$ 5\% \\
\hline EDUC & 1.853670 & 0.0638 & Significant at a 10\% \\
\hline DEP & -0.413171 & 0.6795 & Insignificant \\
\hline RESP & 1.333223 & 0.1825 & Insignificant \\
\hline
\end{tabular}

Table 2. The Influence of Economic and Non-Economic Factors on the Children Health

\begin{tabular}{|c|c|c|c|}
\hline Variable & $\mathbf{Z}_{\text {count }}$ & Prob & Influence \\
\hline HEALTHEXP & -1.422347 & 0.1549 & Insignificant \\
\hline AGE & -2.157694 & 0.0310 & Significant at a 5\% \\
\hline EDUC & 0.030748 & 0.9755 & Insignificant \\
\hline DEP & 0.499963 & 0.6171 & Insignificant \\
\hline RESP & 2.520597 & 0.0117 & Significant at a 5\% \\
\hline
\end{tabular}

Table 3. The Influence of Economic and Non-Economic Factors on the Entirely Children Education and Health

\begin{tabular}{|c|c|c|c|}
\hline Variable & LR count & Prob & Influence \\
\hline E & 13.72344 & 0.017465 & Significant at a $5 \%$ \\
\hline H & 10.45588 & 0.063302 & Significant at a $10 \%$ \\
\hline
\end{tabular}

The partially test result shows that education expenditures, children ages, and education backgrounds of heads of households significantly affect the children education quality. 
Education expenditures and education backgrounds of heads of households positively affect the children education quality where the higher the education expenditure and education backgrounds of heads of households, the better the children education quality. In contrast, the age variable is negatively influential leading to a lower quality of children education. Accordingly, the internal factors inside the children affect the education quality like learning motivation.

The children health variable as shown in Table 2 shows that the children health variable and responsibility significantly affect the children health quality. In addition, children ages negatively affect the children health quality. The older they become, the lower the children health quality. Therefore, children will become more frequently to suffer from illness. The responsibility variable positively affects the children health quality. Children nurtured by their fathers will likely be healthier instead of nurtured by other family members. Consequently, the responsibility function of children nurturing whose mothers work overseas affects the children education and health quality.

The entirely research outcome shows that those five independent variables significantly affect the dependent variable. In addition, remittance, children ages, education backgrounds of heads of household, dependences, and responsibilities significantly influence the children health and education.

\section{CONCLUSION}

Based on the research outcome above, some conclusions can be drawn as follows:

1. Education expenditures, children ages, and education backgrounds of heads of households significantly affect the children education quality of households of Indonesian Female Migrant Workers (TKW).

2. Children ages and the responsibility of children nurturing significantly affect the children health of households of Indonesian Female Migrant Workers (TKW).

\section{References}

Bakker, Caroline. 2009. The impact of migration on children in the Caribbean; UNICEF Office for Barbados and Eastern Caribbean

Carballo, Manuel. 2005. International Migration and Health. Global Commission on International Migration: A paper prepared for the Policy Analysis and Research Programme

Chotib. 2010. Mobilitas Penduduk: Migrasi. Kajian Kependudukan dan Ketenagakerjaan. Program Pasca Sarjana UI.

Danim, Sudarwan. 2004. Ekonomi Sumber Daya Manusia. Bandung: CV Pustaka Setia. 
Oishi, Nana.2002. Gender and Migration: An Integrative Approach. CCIS University of California San Diego; Working Paper 49

Ponce, Juan. 2008. A Case Study of the Impact of Remittances on Human Development in Ecuador. Facultad Latinoamericana de Ciencias Sociales (FLACSO) - Ecuador

PPK-PSDM Unpad. 2007. Studi Remitansi Tenaga Kerja Wanita Indonesia; Pola, Dampak, dan Implikasi Kebijakan. Lembaga Penelitian; Universitas Padjajaran

Ssengonzi, Robert. 2002. The effect of female migration on infant survival in Uganda. Kluwer Academic Publisher

Todaro, MP. 2004. Pembangunan Ekonomi di Dunia Ketiga. Jakarta: Erlangga

Smith, Adam, 1776. An Inquiry into the Nature and Causes of the Wealth of Nations. W. Strahan and T Cadell, London.

Suparmoko, M. 2002. Ekonomika Pembangunan Edisi Keenam. Yogyakarta:BPF

Widarjono, Agus. 2005. Ekonometrika Teori dan Aplikasi. Yogyakarta: FE UI

Knight, D. B., Mappen, E. F., \& Knight, S. L. (2011). A review of the literature on increasing the representation of women undergraduates in STEM disciplines through civic engagement pedagogies. Science Education and Civic Engagement, 3, 36-47.

Sylvia Beyer. (2014). Why are women underrepresented in Computer Science? Gender differences in stereotypes, self-efficacy, values, and interests and predictors of future CS course-taking and grades. Computer Science Education, Vol. 24, Nos. 2-3, 153192, http://dx.doi.org/10.1080/08993408.2014.963363

Hannelore Vandebroek and Leen Van Molle, "The Era of the Housewife? The Construction of 'Work' and the 'active' population in the Belgian population census (1947, 1961 \& 1970)," Belgisch Tijdschrift voor Nieuwste Geschiedenis 1-2 (2010): 51-83

Mafruhah, Izza, Totok Sarsito, Evi Gravitiani. 2012. "The Welfare Of The Indonesian Migrant Workers (TKI) In The Land Of A Malay Nation" : A Socio-Economic Analysis". Southeast Asian Journal Of Social And Political Issues, Vol. 1, No. 2, March 2012 : 246-271.

Kristina Matuzeviciute and Mindaugas Butkus. 2016. Remittances, Development Level, and Long-Run Economic Growth. Economies 2016, 4, 28; http://dx.doi.org/10.3390/economies4040028

Michele Ford (2016). Migrant Worker Organizing in Indonesia. Asian and Pacific Migration Journal, 15(3), 313-334. https://doi.org/10.1177/011719680601500302

Boitumelo Khothatso Seepamore (2015) DISTANCE PARENTING - IMPLICATIONS FOR SOCIAL WORK PRACTICE. Social Work/Maatskaplike Werk Vol 52 No 4; Issue 7, pp. 571-588; http://dx.doi.org/10.15270/52-2-531

Moh. Abdul Hakim, Supriyadi, \& Kwartarini W. Yuniarti. (2012). The Contents of Indonesian Child-Parent Attachment: Indigenous and Cultural Analysis, ISSBD Bulletin, Number 2 Serial No. 62, pp. 11-15 
Rika Saraswati (2013). Justice and the identities of women: The case of Indonesian women victims of domestic violence who have access to Family Court. Forum on Public Policy: a journal of the Oxford Round Table, pp. 1-21. 